\title{
Aplikasi Pemetaan Penderita Gizi Buruk di Kota Pekanbaru menggunakan Quantum GIS
}

\author{
Triyani Arita Fitri ${ }^{1}$, Rio Ferdiansyah ${ }^{2}$ \\ 1,2Program Studi Teknik Informatika STMIK Amik Riau \\ Jl. Purwodadi Indah Km. 10,5 Panam Pekanbaru, telp 0761-589561 \\ Email: 1 triyani.stmikriau@ gmail.com, ${ }^{2}$ rio.ferdiansyah@ gmail.com
}

\begin{abstract}
Abstrak
Gizi buruk merupakan salah satu penyakit serius yang masih dihadapi oleh masyarakat di Indonesia. Kota Pekanbaru memiliki cukup banyak kasus gizi buruk, dimana penderita gizi buruk tersebar di beberapa kecamatan. Dinas Kesehatan Kota Pekanbaru belum memiliki aplikasi untuk memetakan penderita gizi buruk yang dapat memberikan informasi lengkap tentang data dan geografis penderita gizi buruk, Tujuan dari penelitian ini adalah untuk membangun sistem informasi mengenai peta sebaran penderita gizi buruk di Kota Pekanbaru. Dalam pembuatan aplikasi ini menggunakan Quantum GIS untuk pembuatan peta Kota Pekanbaru dilengkapi dengan fitur penunjuk lokasi dengan titik koordinat dari google maps. Metode pengembangan sistem yang digunakan adalah System Development Life Cycle Model Waterfall sampai pada tahapan implementasi dan pengujian Blackbox. Hasil yang diperoleh dari penelitian ini adalah sistem informasi geografis pemetaan penderita gizi buruk, yang dapat membantu Dinas Kesehatan Kota Pekanbaru dalam pengolahan data dan pencarian informasi penderita gizi buruk.
\end{abstract}

Kata kunci: Aplikasi Pemetaan,Google maps, , gizi buruk, , Quantum GIS

\begin{abstract}
Malnutrition is one of the serious illnesses still faced by people in Indonesia. Pekanbaru city has enough malnutrition cases, where malnutrition sufferer spread in some district. Pekanbaru City Health Office has no application to map malnutrition sufferer which can give complete information about data and geographic of malnutrition patient, The purpose of this research is to build information system about distribution map of malnutrition patient in Pekanbaru City. In making this application using Quantum GIS for map making Pekanbaru City is equipped with location indicator feature with coordinate point from google maps. System development method used is System Development Life Cycle Model Waterfall to the stages of implementation and testing Blackbox. The results obtained from this research is the geographic information system mapping malnutrition patients, who can help Pekanbaru City Health Office in data processing and information search for malnutrition.
\end{abstract}

Keywords: Application Mappings, Google maps,, malnutrition,, Quantum GIS

\section{Pendahuluan}

Sistem Informasi Geografis (SIG) diartikan sebagai sistem informasi yang digunakan untuk memasukkan, menyimpan, memanggil kembali, mengolah, menganalisis dan menghasilkan data bereferensi geografis atau data geospatial, untuk mendukung pengambilan keputusan dalam perancanaan dan pengolahan penggunaan lahan,sumber daya alam, lingkungan tranfortasi, fasilitas kota, dan pelayanan umum lainya. Komponen utama SIG adalah sistem computer, data geospatial dan pengguna [1]. Sistem Informasi Geografis 
merupakan suatu sistem informasi khusus mengelola data yang memiliki informasi spasial [2]. Informasi geografis yang terdapat dalam sistem informasi geografis dapat berupa informasi wilayah administasi suatu daerah, sebaran penduduk, sebaran kasus penyakit, dan sebagainya. Informasi-informasi yang disajikan melalui peta tersebut merupakan informasi yang sangat penting terutama dalam penyajian data spasial, agar mudah dipahami dan dianalisis oleh pihak lain.

Sistem informasi geografis merupakan salah satu tools yang tepat untuk membantu menganalisa kondisi suatu daerah terhadap penyakit gizi buruk. Dengan adanya Sistem Informasi Geografis informasi mengenai persebaran gizi buruk di suatu wilayah dapat di visualisasikan dalam bentuk peta digital. Dari penelitian sebelumnya yang dilakukan [3] dengan adanya sistem pemetaan dari status gizi balita berbasis web dan menggunakan google map dapat memantau pencapaian untuk program perbaikan gizi masyarakat . Goolge Maps adalah layanan aplikasi dan teknologi pemetaan berbasis web yang disediakan oleh Google, dimana web ini dapat digunakan secara gratis untuk pemakaian non-komersil [4]. Dari penelitian lain yang dilakukan [5] penggunaan sistem informasi geografis untuk memetakan balita dengan gizi buruk dan gizi kurang memberikan petunjuk untuk dapat dianalisis lebih lanjut dan sangat membantu dalam mengidentifikasi bagian yang paling rentan dari masyarakat termasuk dalam hal gizi buruk dan kemiskinan. Gizi buruk (severe malnutrition) adalah suatu istilah teknis yang umumnya dipakai oleh kalangan gizi, kesehatan dan kedokteran. Gizi buruk adalah suatu kondisi dimana seseorang dinyatakan kekurangan nutrisi, atau dengan ungkapan lain status nutrisarinya berada dibawah standar rata-rata [6]. Nutrisari yang dimaksud bisa berupa protein, karbohidrat dan kalori. Kekurangan gizi menahun atau kekurangan gizi tingkat berat bisa diakibatkan oleh kurangnya asupan makanan, pemilihan jenis makanan yang tidak tepat ataupun karena sebab lain seperti adanya penyakit infeksi yang menyebabkan kurang terserapnya nutrisi dari makanan.

Di kota Pekanbaru pada saat ini masih terdapat banyak kasus mengenai penderita gizi buruk, namun sekarang ini pada Dinas Kesehatan belum memiliki sistem informasi yang dapat mencakup keseluruhan data-data penderita gizi buruk di Kota Pekanbaru ini. Untuk itu dibutuhkan sistem yang bisa memberikan informasi lokasi penderita gizi buruk ke dalam bentuk map yang dapat menampilkan informasi mengenai penderita gizi buruk tersebut. Datadata yang dapat digunakan untuk malakukan pemetaan penderita gizi buruk adalah data penderita gizi buruk dan data geografis penderita gizi buruk Diharapkan dengan adanya sistem ini pihak terkait khususnya Dinas Kesehatan dapat dengan mudah mengetahui lokasi penderita gizi buruk yang ada di Kota Pekanbaru dan dapat melakukan penanganan dengan baik terhadap penderita gizi buruk tersebut.

Tujuan dari penelitian ini adalah menghasilkan aplikasi berbasiskan GIS untuk memetakan penderita gizi buruk di Kota Pekanbaru dan menghasilkan laporan penderita gizi buruk berdasarkan kelompok umur dan kecamatan dalam bentuk table dan grafik. Sistem yang dihasilkan diharapkan dapat membantu dinas kesehatan Kota Pekanbaru dalam pendataan dan penyajian informasi penderita gizi buruk di Kota Pekanbaru dengan cepat dan mudah. Dalam aplikasi system informasi geografis ini pembuatan peta digitalnya menggunakan Quantum Gis(QGIS). Quantum GIS adalah aplikasi SIG gratis yang mencakup pemetaan, analisis spasial dan beberapa fitur Desktop GIS lainnya. Aplikasi ini sama dengan paket aplikasi GIS komersial namun aplikasi ini didistribusikan secara gratis dibawah lisensi GNU, Quantum GIS mendukung format data vektor, raster dan database [7]. Pada QGIS ini memiliki keuntungan diantaranya aplikasi ini bersifat open source sehingga siapa saja dapat menggunakannya serta QGIS memiliki tampilan simple dan user friendly. 


\section{Metode Penelitian}

\subsection{Sumber Data}

Sumber data dalam penelitian ini diperoleh dari Dinas Kesehatan Kota Pekanbaru pada Bidang Kesehatan keluarga pada Seksi Gizi melalui observasi dan wawancara untuk mendapatkan data tentang penderita gizi buruk pada kelompok usia $0-59$ bulan di kota Pekanbaru 3 (tiga) tahun terakhir ( 2014,2015 , 2016 ). Data-data tersebut merupakan laporan dari tiap-tiap puskesmas yang ada diseluruh kecamatan Kota Pekanbaru.

\subsection{Tahapan Pengembangan Sistem}

Metode yang digunakan untuk rekayasa perangkat lunak Aplikasi pemetaan penderita gizi buruk adalah adalah System Development Lyfe Cycle (SDLC) model Waterfall . Model ini melakukan pendekatan secara sistematis dan urut mulai dari level kebutuhan sistem sampai dengan penerapan seperti yang ditunjukan seperti yang ditunjukan pada gambar 1 dibawah ini ;

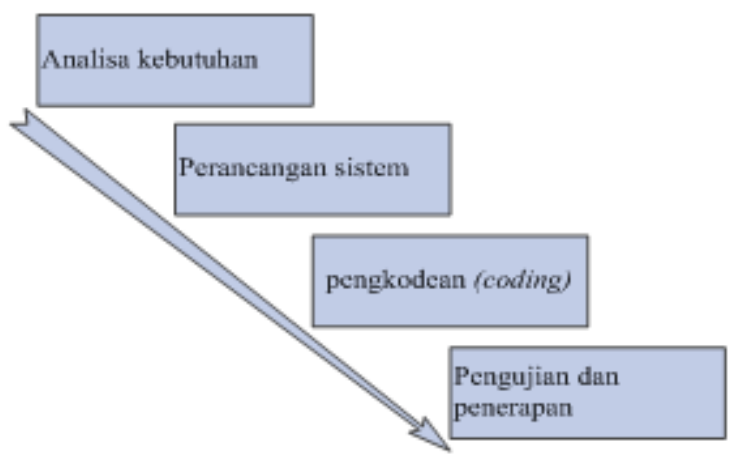

Gambar 1. Rancangan Pengembangan Sistem [8]

Uraian kegiatan yang dilakukan pada setiap tahap adalah sebagai berikut :

1. Analisis Kebutuhan

Tahap ini dilakukan untuk mengumpulkan semua data yang terkait dalam pembuatan sistem dan informasi yang akan dijadikan dasar pembuatan sistem. Pada tahap ini data dan informasi penderita gizi buruk yang telah diperoleh dianalisa terlebih dahulu untuk mendapatkan input dan output yang akan dihasilkan.

2. Perancangan sistem

Pemodelan perancangan sistem ini menggunakan diagram UML (Unified Modelling Language), perancangan antarmuka sistem pengguna, dan spesifikasi proses [9]. Pada diagram UML yang dirancang adalah use case diagram, activity diagram, sequence diagram. Perancangan UML digunakan untuk memperjelas data yang dapat di akses oleh adiministrator dan pengguna. Dokumen yang dipersiapkan pada tahap ini adalah Process Modeling, Data Modeling, dan Interface Modeling.

3. Coding

Pembuatan kode - kode program pada tahap ini berdasarkan pada hasil seluruh rancangan yang telah dihasilkan pada tahap sebelumnya. Pengkodean dilakukan dengan menggunakan bahasa pemrograman PHP dan MySQL (My Structured Query Language) sebagai databasenya. Sedangkan untuk pembuatan peta polygon menggunakan Quantum GIS (QGIS 2.18.2). Software pendukung lainnya adalah XAMPP 3.2.2 sebagai web server dan Google chrome sebagai web browser. Kegiatan ini dimulai dengan pembuatan peta , pembuatan database dan coding. 


\section{Pengujian}

Pada tahap pengujian digunakan black box testing yang merupakan pendekatan pengujian dengan mempelajari input dan output yang diberikan[10].Tahapan pengujian ini dilakukan dengan tujuan untuk menjamin sistem yang dibuat sesuai dengan hasil analisis dan perancangan serta menghasilkan satu kesimpulan apakah sistem tersebut sesuai dengan yang diharapkan.

\section{Hasil dan Pembahasan}

\subsection{Proses Digitasi ke dalam format Shapefile}

Data yang digunakan dalam sistem informasi geografis ini adalah Peta Kota Pekanbaru yang diperoleh dalam bentuk tampilan gambar. Data peta tersebut diperoleh dari internet yang dapat dilihat pada gambar 2, Peta tersebut meliputi kecamatan-kecamatan yang ada di Kota Pekanbaru.

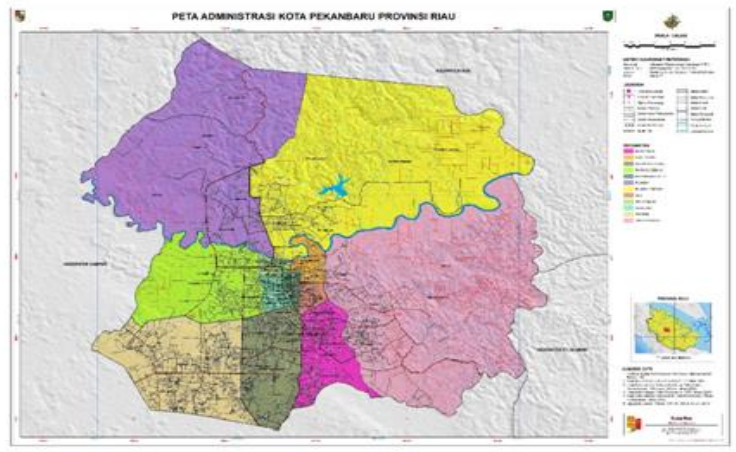

Gambar 2. Peta Administrasi Kota Pekanbaru

Peta tersebut harus di digitasi agar dapat digunakan pada sistem yang dibuat. Proses digitasi dilakukan dengan menggunakan aplikasi QGIS2.18.2 untuk mendapatkan format shapefile. Adapun tahap pendigitasian tersebut sebagai berikut:

a. Menambah lapisan vector peta Indonesia

Gambar 3 menunjukan proses memuat data vector peta Indonesia yang sudah dalam format shapefile dalam layer melalui menu Layer >Add vector Layer. Data vector yang digunakan adalah dalam bentuk polygon.

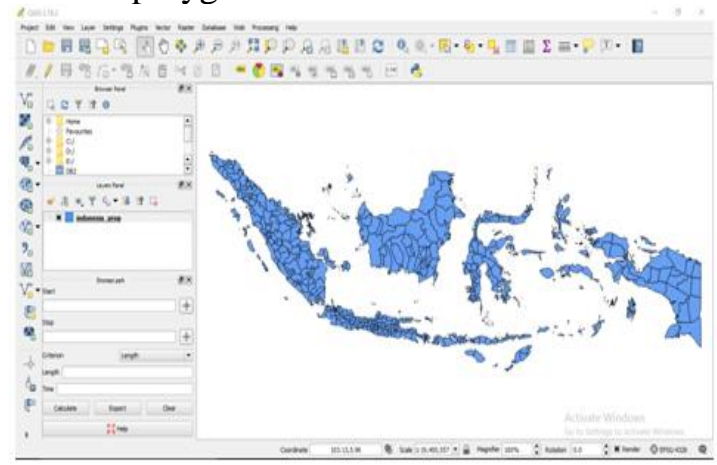

Gambar 3. Proses memuat data vector peta Indonesia dalam layer

b. Menambah lapisan vector batas administrasi Provinsi Riau

Gambar 4 menunjukan proses memuat data vector batas administrasi Provinsi Riau pada peta Indonesia yang sudah dalam format shapefile dalam layer. Proses memuat melalui menu 
Layer > Add vector Layer. Data vector yang digunakan adalah dalam bentuk polygon.

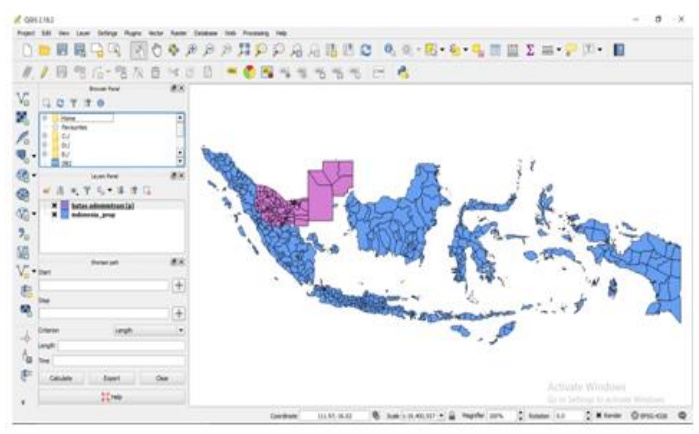

Gambar 4. Proses memuat data vector batas administrasi Provinsi Riau

c. Membuat data raster peta administrasi kota Pekanbaru

Dalam membuat data raster peta administrasi kota Pekanbrau digunakan file raster berupa file gambar yang berekstensi.TIF. Gambar 5 menunjukan proses memasukan data raster peta administrasi kota Pekanbaru dalam format TIF melalui menu Layer > Add Raster Layer. Proses ini bertujuan untuk mendigitasi peta kota Pekanbaru.

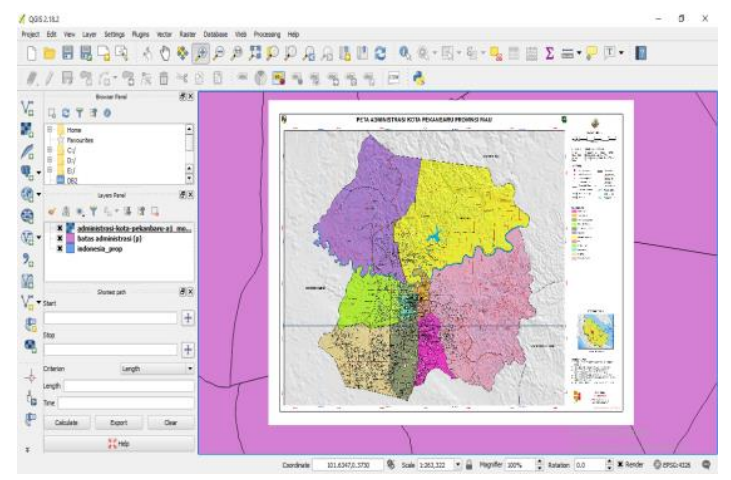

Gambar 5. Proses membuat data raster peta administrasi kota Pekanbaru

d. Proses Digitasi peta kota Pekanbaru

Langkah berikutnya adalah melakukan proses digitasi peta Pekanbaru untuk setiap kecamatan . Hasil digitasi dapat dilihat pada gambar 6 dalam bentuk area ( polygon )

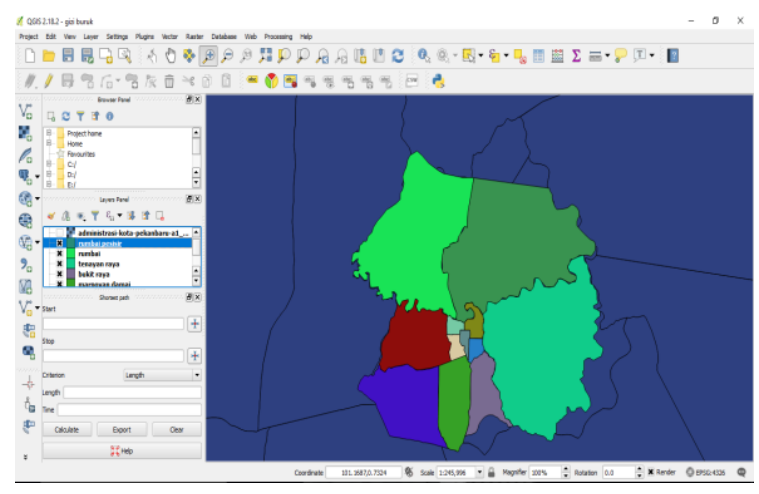

Gambar 6. Proses Digitasi peta Kota Pekanbaru 
3.2 Implementasi antar muka (interface)

Berikut adalah tampilan antar muka dari sistem informasi geografis pemetaan penderita gizi buruk di Kota Pekanbaru.

a. Tampilan Halaman Utama Sistem

Tampilan halaman utama sistem adalah tampilan yang dilihat ketika program ini dijalankan, berisi informasi tentang data peta penderita gizi buruk di kota Pekanbaru

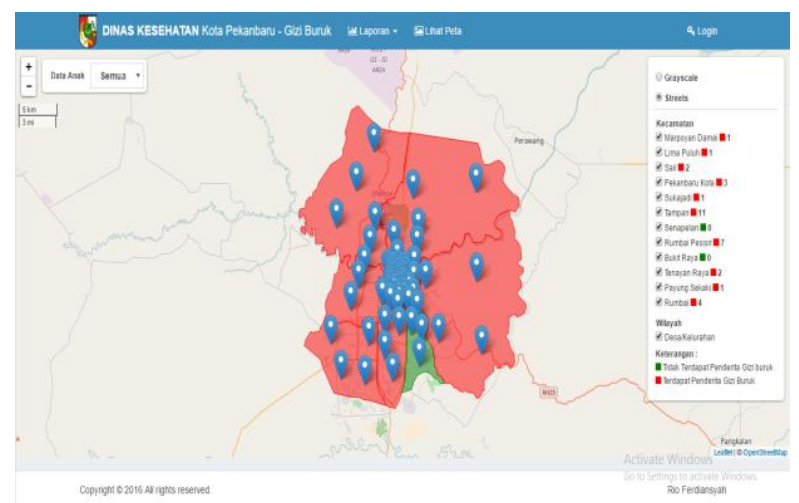

Gambar 7. Tampilan halaman utama sistem

b. Tampilan menu lihat peta

Tampilan menu lihat peta yang ditunjukan pada gambar 8 adalah tampilan yang memberikan informasi kepada pengguna mengenai peta penderita gizi buruk di setiap kecamatan yang ada di kota Pekanbaru. Pengguna dapat melihat secara lengkap dan detail data penderita gizi buruk di setiap kecamatan di kota Pekanbaru.

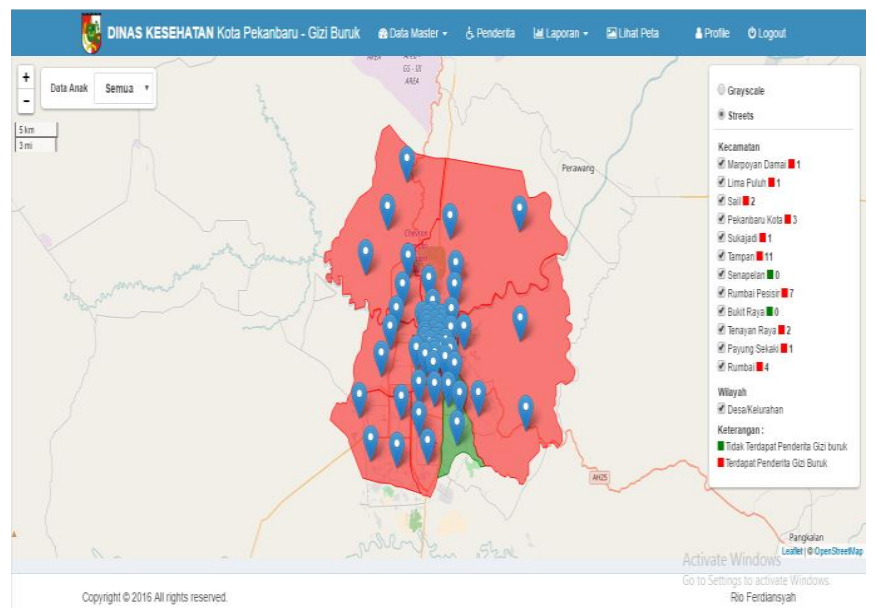

Gambar 8. Tampilan menu lihat peta

c. Tampilan Menu Laporan Rekapitulasi

Laporan ini berisikan hasil rekapitulasi jumlah penderita gizi buruk untuk setiap kecamatan di kota Pekanbaru . Identitas detail dari penderita gizi buruk dapat dilihat pada menu Laporan Rekapitulasi seperti yang ditunjukan pada gambar 9 dibawah ini : 


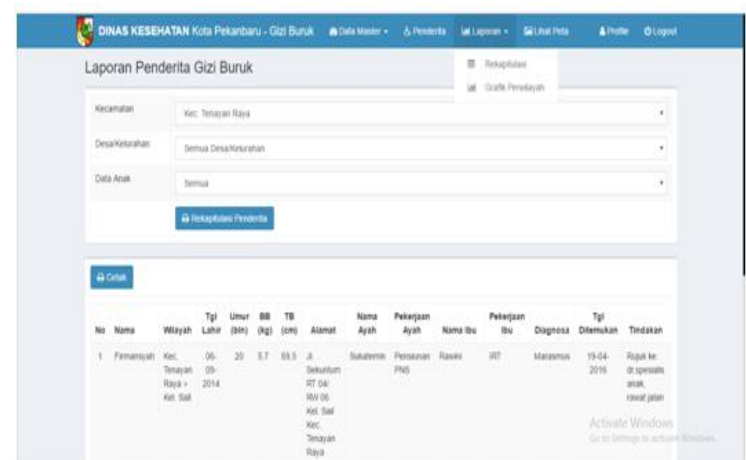

Gambar 9. Tampilan Menu Laporan Rekapitulasi

d. Tampilan Cetak Rekapitulasi

Gambar 10 menunjukan tampilan cetak laporan rekapitulasi penderita gizi buruk untuk setiap kecamatan di kota Pekanbaru.

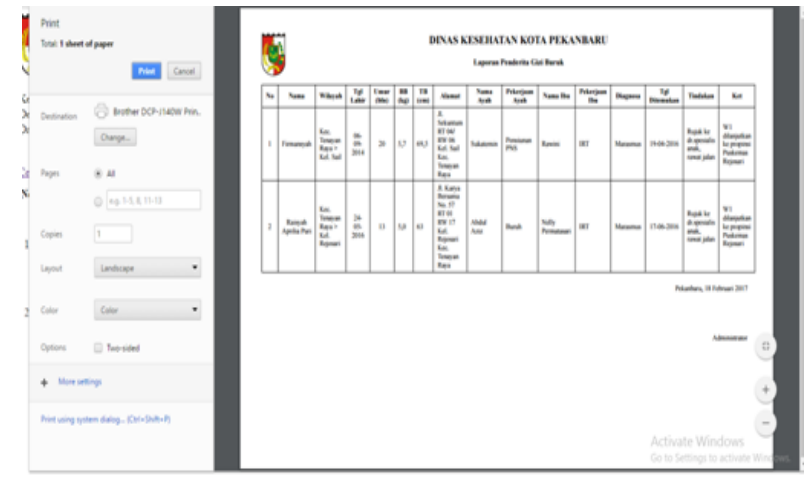

Gambar 10. Tampilan Cetak Rekapitulasi

e. Tampilan Laporan Grafik

Tampilan Laporan grafik memberikan informasi jumlah penderita gizi buruk pada setiap kecamatan di kota Pekanbaru. Grafik dalam bentuk bar dipilih untuk menggambarkan jumlah penderita setiap kecamatan maupun unuk seluruh kecamatan yang ada di kota Pekanbaru, seperti yang ditunjukan pada gambar 11 dibawah ini :

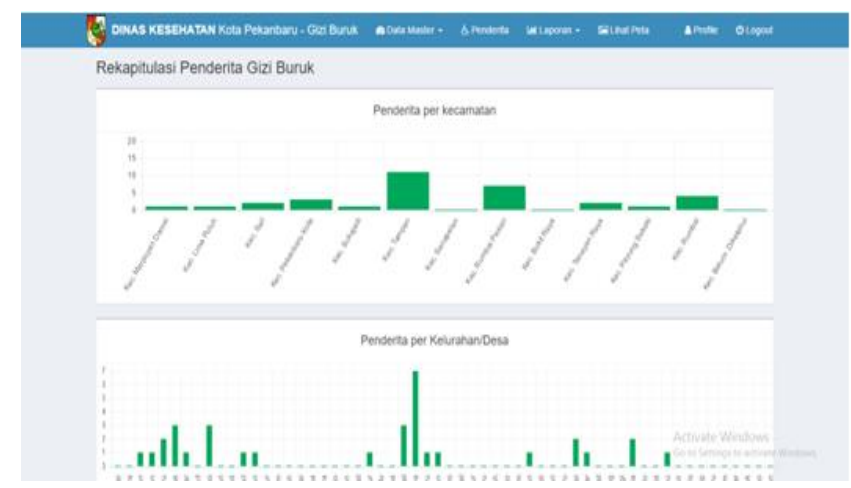

Gambar 11. Tampilan Laporan grafik perwilayah 


\subsection{Teknik Pengujian}

Teknik pengujian sistem informasi geografis untuk memetakan penderita gizi buruk di Kota Pekanbaru ini menggunakan teknik pengujian black box.Teknik pengujian black box adalah bagaimana bentuk pengujian ini memperlihatkan masukan yang diterima dengan baik dan keluaran yang dihasilkan dengan cepat. Pengujian black box ini juga mengidentifikasi kesalahan yang berhubungan dengan kesalahan fungsionalitas perangkat lunak yang tampak dalam kesalahan output.

a. Rencana Pengujian

Pengujian sistem pemetaan penderita gizi buruk di Kota Pekanbaru berikut menggunakan data uji berupa login sistem, proses input data dan pengujian peta seperti tertuang pada tabel 1 .

Tabel 1. Rencana pengujian

\begin{tabular}{|l|l|l|}
\hline Kelas Uji & \multicolumn{1}{|c|}{ Butir Uji } & Jenis Pengujian \\
\hline Login & $\begin{array}{l}\text { Pengecekan user name dan password yang } \\
\text { sudah ada }\end{array}$ & Black Box \\
\hline $\begin{array}{l}\text { Input } \\
\text { data }\end{array}$ & $\begin{array}{l}\text { Input data pengguna, kecamatan, } \\
\text { desa/kelurahan.termasuk ubah dan hapus }\end{array}$ & Black Box \\
\hline $\begin{array}{l}\text { Pengujian } \\
\text { peta }\end{array}$ & Melihat informasi ouput peta & Black Box \\
\hline
\end{tabular}

b. Kasus dan Hasil Pengujian

Dalam melakukan pengujian, tentu saja ada objek yang harus diuji dimana setelah itu akan didapat hasil dari pengujian tersebut. Kasus dan Hasil Pengujian terdiri dari pengujian login, pengujian menu pengguna, pengujian menu penderita, dan pengujian lihat peta .

\section{b.1. Pengujian Login}

Kasus dan hasil pengujian pada pengujian login dilakukan untuk data normal dan data salah . Hasil pengujian dapat dilihat pada tabel 2 dibawah ini :

Tabel 2. Pengujian Login Sistem

\begin{tabular}{|l|l|l|c|}
\hline \multicolumn{4}{|c|}{ Kasus dan Hasil Uji ( Data Normal) } \\
\hline \multicolumn{1}{|c|}{ Data } & Yang di harapkan & Pengamatan & Kesimpulan \\
\hline $\begin{array}{l}\text { Username : admin } \\
\text { Password : admin }\end{array}$ & $\begin{array}{c}\text { Menampilkan } \\
\text { menu utama }\end{array}$ & $\begin{array}{c}\text { Menu utama } \\
\text { tampil }\end{array}$ & Diterima \\
\hline \multicolumn{3}{|c|}{ Kasus dan Hasil Uji ( Data Salah) } \\
\hline $\begin{array}{l}\text { Username : rioferdi } \\
\text { Password : rio }\end{array}$ & $\begin{array}{l}\text { Menampilkan } \\
\text { Peringatan }\end{array}$ & $\begin{array}{l}\text { Pesan } \\
\text { peringatan } \\
\text { muncul }\end{array}$ & Diterima \\
\hline
\end{tabular}

\section{b.2. Pengujian Menu Pengguna}

Pada menu pengguna dilakukan pengujian terhadap menu pengguna, menu kecamatan, dan menu desa/ kelurahan. Kasus dan hasil pengujian pada setiap menu dilakukan untuk data normal dan data salah . Hasil pengujian untuk setiap menu dituangkan pada tabel 3, tabel 4 dan tabel 5 . 
Tabel 3. Pengujian Menu Pengguna

\begin{tabular}{|l|l|l|l|}
\hline \multicolumn{4}{|c|}{ Kasus dan Hasil Uji ( Data Normal) } \\
\hline Data & Yang di harapkan & Pengamatan & Kesimpulan \\
\hline $\begin{array}{l}\text { Tambah pengguna } \\
\text { Nama : rio ferdiansyah } \\
\begin{array}{l}\text { Username : rio } \\
\text { Password : rio }\end{array}\end{array}$ & $\begin{array}{l}\text { Data masuk ke } \\
\text { dalam } \\
\text { database }\end{array}$ & $\begin{array}{l}\text { Data pengguna } \\
\text { masuk ke dalam } \\
\text { data base }\end{array}$ & Diterima \\
\hline $\begin{array}{l}\text { Ubah pengguna } \\
\text { Nama : rio f menjadi } \\
\text { rio f }\end{array}$ & $\begin{array}{l}\text { Data dapat diubah } \\
\text { hingga data lama } \\
\text { dapat dirubah } \\
\text { menjadi data yang } \\
\text { baru }\end{array}$ & $\begin{array}{l}\text { Data pada } \\
\text { database } \\
\text { berubah }\end{array}$ & Diterima \\
\hline $\begin{array}{l}\text { Penghapusan data } \\
\text { pengguna } \\
\text { Nama : rio f }\end{array}$ & $\begin{array}{l}\text { Data pengguna } \\
\text { dapat dihapus pada } \\
\text { database }\end{array}$ & $\begin{array}{l}\text { Data pengguna } \\
\text { terhapus } \\
\text { Pada database }\end{array}$ & Diterima \\
\hline Kasus dan Hasil Uji ( Data Salah) & $\begin{array}{l}\text { Menampilkan } \\
\text { pesan peringatan } \\
\text { Tambah penggunan } \\
\text { dengan username } \\
\text { sudah ada di database } \\
\text { Username : rio }\end{array}$ & $\begin{array}{l}\text { peringatan } \\
\text { muncul }\end{array}$ & Diterima \\
\hline
\end{tabular}

Tabel 4. Pengujian Menu Kecamatan

\begin{tabular}{|c|c|c|c|}
\hline \multicolumn{4}{|c|}{ Kasus dan Hasil Uji ( Data Normal) } \\
\hline Data & Yang di harapkan & Pengamatan & Kesimpulan \\
\hline $\begin{array}{l}\text { Tambah } \\
\text { kecamatan } \\
\text { Nama kecamatan : } \\
\text { Tenayan raya }\end{array}$ & $\begin{array}{l}\text { Data masuk ke dalam } \\
\text { database }\end{array}$ & $\begin{array}{l}\text { Data kecamatan } \\
\text { masuk ke dalam } \\
\text { data base }\end{array}$ & Diterima \\
\hline $\begin{array}{l}\text { Ubah kecamatan } \\
\text { Kecamatan } \\
\text { Tenayan Raya tes } \\
\text { menjadi Tenayan } \\
\text { Raya tes }\end{array}$ & $\begin{array}{l}\text { Data dapat diubah } \\
\text { hingga data lama dapat } \\
\text { dirubah menjadi data } \\
\text { yang baru }\end{array}$ & $\begin{array}{l}\text { Data pada } \\
\text { database berubah }\end{array}$ & Diterima \\
\hline $\begin{array}{l}\text { Penghapusan data } \\
\text { kecamatana }\end{array}$ & $\begin{array}{l}\text { Data pengguna dapat } \\
\text { dihapuspada database }\end{array}$ & $\begin{array}{l}\text { Data pengguna } \\
\text { terhapus }\end{array}$ & Diterima \\
\hline \multicolumn{4}{|c|}{ Kasus dan Hasil Uji ( Data Salah) } \\
\hline $\begin{array}{l}\text { Tambah } \\
\text { kecamatan dengan } \\
\text { nama kecamatan } \\
\text { yang sudah ada di } \\
\text { database } \\
\text { Kecamatan : } \\
\text { Tenayan raya }\end{array}$ & $\begin{array}{l}\text { Menampilkan } \\
\text { pesan peringatan }\end{array}$ & $\begin{array}{l}\text { Pesan peringatan } \\
\text { muncul }\end{array}$ & Diterima \\
\hline
\end{tabular}


Tabel 5. Pengujian Menu Desa/Kelurahan

\begin{tabular}{|c|c|c|c|}
\hline \multicolumn{4}{|c|}{ Kasus dan Hasil Uji ( Data Normal) } \\
\hline Data & Yang di harapkan & Pengamatan & Kesimpulan \\
\hline $\begin{array}{l}\text { Tambah } \\
\text { Desa/Kelurahan } \\
\text { Nama : baru }\end{array}$ & $\begin{array}{l}\text { Data masuk ke } \\
\text { dalam } \\
\text { database }\end{array}$ & $\begin{array}{l}\text { Data Desa/Kelurahan } \\
\text { masuk ke dalam data } \\
\text { base }\end{array}$ & Diterima \\
\hline $\begin{array}{l}\text { Ubah nama } \\
\text { Desa/Kelurahan } \\
\text { baru menjadi } \\
\text { bukan baru }\end{array}$ & $\begin{array}{l}\text { Data dapat diubah } \\
\text { hingga data lama } \\
\text { dapat dirubah } \\
\text { menjadi data yang } \\
\text { baru }\end{array}$ & $\begin{array}{l}\text { Data pada database } \\
\text { berubah }\end{array}$ & Diterima \\
\hline $\begin{array}{l}\text { Penghapusan data } \\
\text { Desa/Kelurahan } \\
\text { dengan nama } \\
\text { bukan baru }\end{array}$ & $\begin{array}{l}\text { Data } \\
\text { Desa/Kelurahan } \\
\text { dapat dihapuspada } \\
\text { database }\end{array}$ & $\begin{array}{l}\text { Data } \\
\text { Desa/Kelurahanterhapus } \\
\text { pada database }\end{array}$ & Diterima \\
\hline \multicolumn{4}{|c|}{ Kasus dan Hasil Uji ( Data Salah) } \\
\hline $\begin{array}{l}\text { Tambah } \\
\text { Desa/Kelurahan } \\
\text { dengan nama } \\
\text { Desa/Kelurahan } \\
\text { yang sudah ada di } \\
\text { database } \\
\text { Potensi : baru }\end{array}$ & $\begin{array}{l}\text { Menampilkan } \\
\text { pesan peringatan }\end{array}$ & $\begin{array}{l}\text { Pesan peringatan } \\
\text { muncul }\end{array}$ & Diterima \\
\hline
\end{tabular}

b.3. Pengujian Menu Penderita

Pengujian tambah,ubah,hapus penderita adalah sebagai berikut :

Tabel 6. Pengujian Menu Penderita

\begin{tabular}{|l|l|l|l|}
\hline \multicolumn{4}{|c|}{ Kasus dan Hasil Uji ( Data Normal) } \\
\hline Data & Yang di harapkan & Pengamatan & Kesimpulan \\
\hline $\begin{array}{l}\text { Tambah Penderita } \\
\text { dengan Nama : coba }\end{array}$ & $\begin{array}{l}\text { Data masuk ke dalam } \\
\text { database }\end{array}$ & $\begin{array}{l}\text { Data penderita } \\
\text { masuk ke } \\
\text { dalam data base }\end{array}$ & Diterima \\
\hline $\begin{array}{l}\text { Ubah data penderita } \\
\text { dengan nama coba } \\
\text { menjadi coba aja }\end{array}$ & $\begin{array}{l}\text { Data dapat diubah } \\
\text { hingga data lama dapat } \\
\text { dirubah menjadi data } \\
\text { yang baru }\end{array}$ & $\begin{array}{l}\text { Data pada } \\
\text { database } \\
\text { berubah }\end{array}$ & Diterima \\
\hline $\begin{array}{l}\text { Penghapusan data } \\
\text { penderita dengan } \\
\text { nama coba saja }\end{array}$ & $\begin{array}{l}\text { Data penderita dapat } \\
\text { dihapus pada database }\end{array}$ & $\begin{array}{l}\text { Data penderita } \\
\text { terhapus } \\
\text { pada database }\end{array}$ & Diterima \\
\hline \multicolumn{4}{|l|}{ Kasus dan Hasil Uji ( Data Salah) } \\
\hline $\begin{array}{l}\text { Tambah penderita } \\
\text { berada di wilayah } \\
\text { mana }\end{array}$ & $\begin{array}{l}\text { Menampilkan } \\
\text { pesan peringatan }\end{array}$ & $\begin{array}{l}\text { Pesan } \\
\text { peringatan } \\
\text { muncul }\end{array}$ & Diterima \\
\hline
\end{tabular}




\begin{tabular}{|l|l|l|l|}
\hline $\begin{array}{l}\text { Tambah penderita } \\
\text { tanpa memilih } \\
\text { tanggal ditemukan }\end{array}$ & $\begin{array}{l}\text { Menampilkan } \\
\text { pesan peringatan }\end{array}$ & $\begin{array}{l}\text { Pesan } \\
\text { peringatan } \\
\text { muncul }\end{array}$ & Diterima \\
\hline
\end{tabular}

\section{b.4. Pengujian Lihat Peta}

Kasus dan hasil pengujian pada pengujian lihat peta login dilakukan untuk data normal dan data salah. Hasil pengujian dapat dilihat pada tabel 2 dibawah ini :

Tabel 7. Pengujian Lihat Peta

\begin{tabular}{|l|l|l|l|}
\hline \multicolumn{4}{|c|}{ Kasus dan Hasil Uji ( Data Normal) } \\
\hline Data & Yang di harapkan & Pengamatan & Kesimpulan \\
\hline $\begin{array}{l}\text { Pilih menu lihat } \\
\text { peta dalam } \\
\text { keadaan } \text { online }\end{array}$ & $\begin{array}{l}\text { Muncul peta google } \\
\text { mapsdan peta kota Pekanbaru }\end{array}$ & $\begin{array}{l}\text { peta google } \\
\text { maps dan peta } \\
\text { Kota Pekanbaru } \\
\text { muncul }\end{array}$ & Diterima \\
\hline \multicolumn{4}{|c|}{ Kasus dan Hasil Uji ( Data Salah) } \\
\hline $\begin{array}{l}\text { Pilih menu lihat } \\
\text { peta dalam } \\
\text { keadaan } \text { offline }\end{array}$ & $\begin{array}{l}\text { Peta google maps tidak } \\
\text { muncul }\end{array}$ & $\begin{array}{l}\text { Peta google } \\
\text { maps tidak } \\
\text { muncul }\end{array}$ & Diterima \\
\hline
\end{tabular}

d. Kesimpulan hasil Pengujian

Berdasarkan hasil pengujian dengan kasus black box, maka dapat diambil kesimpulan sebagai berikut :

1. Antar muka sistem yang dibangun cukup baik dan mudah digunakan

2. Fungsi-fungsi yang dijalankan sistem sudah benar sesuai dengan apa yang diharapkan dan dirancang.

3. Menampilkan pesan peringatan jika data tidak sesuai dengan database.

4. Menampilkan pesan peringatan jika data sudah ada didalam database (data sama).

5. Peta google maps tidak akan tampil jika sistem digunakan dalam kondisi offline atau tidak terhubung ke jaringan internet.

\section{Kesimpulan}

Hasil dari penelitian ini adalah tersedianya sistem pemetaan penderita gizi buruk di Kota Pekanbaru menggunakan Quantum QIS yang dapat membantu Dinas Kesehatan Kota Pekanbaru dalam memantau jumlah penderita gizi buruk berdasarkan wilayah geografis, kelompok umur dan periode waktu. Aplikasi yang dihasilkan dapat menyajikan informasi geografis penderita gizi buruk anak usia 0-5 tahun di kota Pekanbaru berdasarkan wilayah kecamatan. Sedangkan data detail dan jumlah penderita gizi buruk yang ada disetiap kecamatan dapat disajikan dalam bentuk tabel dan grafik. Informasi yang disajikan dapat dipilih berdasarkan kelompok umur dan tahun pencarian . 


\section{Daftar Pustaka}

[1] Maita, I . Konsep Sistem Informasi Geografis, Pekanbaru : Yayasan Pustaka Riau . 2011

[2] Nur Rizky, YR, Aplikasi Sistem Informasi Geografis Berbasis WEB untuk Persebaran Sekolah Menengah Atas, Jurnal Geodesi Undip , 2015;4(1);173

[3] Setyowati, Maryati , Pemetaan Status Gizi Balita dalam Mendukung Keberhasilan Pencapaian Millenium Development Goals (MDGs) ,Jurnal Kesehatan Masyarakat ,2015;10 (2), $110-121$

[4] Pramartha, I. M. A. Implementasi Aplikasi Sig Dalam Pengolahan Data Jumlah Penduduk Berbasis Web. Jurnal Elektronik Ilmu Komputer, 2012;1(2); 87-91.

[5] Tarmizi , Pemantauan Penanganan Kasus Balita Gizi Buruk dengan menggunakan Sistem Informasi Spasial di Kota Banda Aceh, , Jurnal Sisitem Informasi Kesehatan Masyarakat,2016;1(1);32-38

[6] Lumbanbatu, Katen , Sistem Pakar Mendiagnosa Gizi Buruk pada Balita dengan Metode Fuzzy Logic ,Jurnal Kaputama, 2014; 8(1); 12

[7] Irwansyah,Edy . Sistem Informasi Geografis, Yogyakarta : Digiboks. 2013

[8] A.S,R,\&Shalahuddin,M . Rekayasa Perangkat Lunak Terstruktur dan Berprientasikan Objek. Bandung: Informatika. 2013

[9] Munawar, Pemodelan Visual dengan UML, Jakarta; Graha Ilmu,2005

[10] Kadir,Abdul, Pengenalan Sistem Informasi, Yogyakarta;Andi Offset,2003 